\title{
Selected Predictors of Consumer Ethnocentrism in the Food Market (Gender Differences)
}

\author{
Paweł Bryła (D)
}

check for updates

Citation: Bryła, P. Selected Predictors of Consumer Ethnocentrism in the Food Market (Gender Differences). Energies 2021, 14, 7667. https:// doi.org/10.3390/en14227667

Academic Editor: Karolina Pawlak

Received: 19 October 2021

Accepted: 14 November 2021

Published: 16 November 2021

Publisher's Note: MDPI stays neutral with regard to jurisdictional claims in published maps and institutional affiliations.

Copyright: (C) 2021 by the author. Licensee MDPI, Basel, Switzerland. This article is an open access article distributed under the terms and conditions of the Creative Commons Attribution (CC BY) license (https:/ / creativecommons.org/licenses/by/ $4.0 /)$.
Department of International Marketing and Retailing, Faculty of International and Political Studies, University of Lodz, Narutowicza 59a, 90-131 Lodz, Poland; pawel.bryla@uni.lodz.pl; Tel.: +48-426655830

\begin{abstract}
This paper aims to identify predictors of consumer ethnocentrism in the food market. An online survey was conducted in a sample of 1000 Polish consumers, which was representative by sex, age, education level, urban-rural divide, and region. The 10-item CETSCALE was applied. In a retrograde stepwise regression model, consumer ethnocentrism in the food market was positively related to tradition and conformity Schwartz values, to the pride of being Polish, and to such product characteristics as the country of origin, distance from the producer, and natural content. It was negatively related to the universalism value and to being a student. To gain further insights into the predictors of consumer ethnocentrism in the food market for either gender, separate regressions were conducted among men and women. Three predictors affected positively and significantly consumer ethnocentrism in the food market both among men and among women, namely the tradition Schwartz value, pride of being Polish, and importance attached to distance covered by the food product from the producer to the shop, which is related to the preference for local food. Moreover, consumer ethnocentrism among men was dependent on their food choice motive-environmental friendliness, whereas consumer ethnocentrism among women was affected by the importance attached to the product's country of origin, and it was negatively related to women's younger age.
\end{abstract}

Keywords: consumer ethnocentrism; food market; CETSCALE; food consumption; Schwartz values; theory of human values; Food Choice Questionnaire (FCQ); gender differences; country of origin (COO); local food

\section{Introduction}

Consumer ethnocentrism is an important consideration in marketing and consumer behavior studies. The willingness to buy domestic products is predicted by consumer ethnocentrism [1]. The intention to buy the product increases significantly with the presence of the "made in the domestic country" label. This effect increases with consumer ethnocentrism and attachment to national identity and diminishes with brand equity [2]. It was found to have a positive effect on brand equity for domestic brands [3]. It may affect not only behavioral intentions but also the perception of quality [4]. It enhances consumers' willingness to pay for domestically produced food [5]. Consumer ethnocentrism raises psychosocial and performance risk perceptions and lowers the propensity to buy foreign products [6]. The key antecedent of correct country-of-origin identification is consumer ethnocentrism [7]. There is a negative relation between consumer ethnocentrism and the complexity of product knowledge [8]. The impact of consumer ethnocentrism on the bias in favor of domestic products varies by the country of origin and the product category [9]. Product category should be taken into consideration in studies of consumer ethnocentrism [10]. Consumer ethnocentrism is a significant factor that should be taken into account in creating promotional campaigns for dairy products [11]. Consumer ethnocentrism positively predisposes favorable domestic product judgments [12]. Consumer ethnocentrism is strongly associated with the importance of country-of-origin information on the food label [13]. The influence of country-related effect on trust is negatively related to consumer ethnocentrism [14]. 
Although consumer ethnocentrism has been a popular research topic, there are relatively few studies conducted in representative nationwide samples, which investigate a wide range of sociodemographic predictors. Moreover, the research gap stems from the need to focus on a single product category, which entails the possibility to use constructs which are specific to this category (e.g., the importance attached to food attributes and food choice criteria). Third, the extant literature often lacks a systematic approach to studying the simultaneous impact of various predictors. This limitation can be overcome by applying advanced statistical modelling. It is important to identify predictors of consumer ethnocentrism in the food market not only from the theoretical standpoint but also to improve the effectiveness of marketing communications addressed to the ethnocentric segment of consumers. Moreover, it is important to check whether these predictors differ between genders in order to obtain a more precise picture of consumer ethnocentrism in the food market.

This research aims to identify predictors of consumer ethnocentrism in the food market both in the total sample and for either gender separately. The following research questions will be addressed in this article:

RQ1. Which consumer characteristics affect consumer ethnocentrism in the food market?

RQ2. What are the predictors of consumer ethnocentrism in the food market among men?

RQ3. What are the predictors of consumer ethnocentrism in the food market among women?

\section{Literature Review}

Four categories of predictors of consumer ethnocentrism were found in the literature: sociopsychological, political, economic, and demographic [15]. De Ruyter et al. [16] identified the following demographic antecedents of consumer ethnocentrism: age, gender, education, and income, as well as such sociopsychological factors as openness to foreign cultures, patriotism, conservatism, and collectivism/individualism. The relationship between consumer ethnocentrism and willingness to buy is moderated by age and gender [17]. The effect of consumer ethnocentrism on purchasing behavior is moderated by gender, marital status, and personal income [18]. Demographic factors (age and gender) are significant factors in consumer ethnocentrism in the Czech Republic and Slovakia but not in the same direction and strength, which may be due to cultural differences [19]. In Croatia, both genders of ethnocentric consumers are older, less educated, poor, more religious, and dissatisfied with their life [20]. A study in Colombia demonstrated that gender and age are not determinants of ethnocentric consumer tendencies [21]. Gender does not influence the relation between consumer ethnocentrism and lifestyle [22]. As the empirical evidence on the impact of demographic and socioeconomic factors on consumer ethnocentrism is inconsistent, it is justified to examine this phenomenon in the current study (Hypothesis H1).

Hypothesis (H1). Consumer demographic and socioeconomic characteristics affect the consumer ethnocentrism level in the food market.

According to Siamagka and Balabanis [23], consumer ethnocentrism encompasses five dimensions: prosociality, cognition, insecurity, reflexiveness, and habituation. Consumer ethnocentrism is related to personal values, moral foundations, and gender-role identities [24]. Ethnocentric and conservative attitudes were found to coexist [25]. Consumer ethnocentrism is related to proximity, tradition, and ethnicity [26]. Han and Won [27] suggested that Schwartz factors may be relevant antecedents of consumer ethnocentrism and called for their investigation in future studies. These findings led to the formulation of the research hypotheses $\mathrm{H} 2$ and $\mathrm{H} 3$. 
Hypothesis (H2). Consumer Schwartz values affect the consumer ethnocentrism level in the food market.

Hypothesis (H3). Other psychographic characteristics (in addition to Schwartz values) affect the consumer ethnocentrism level in the food market.

Three food attributes (importance attached to the brand, retailer trust, and quality signs) were predictors of regional ethnocentrism in the food market [28], and importance attached to the country-of-origin information was strongly related to the home country product origin [13], so it is justified to investigate the impact of food attributes' evaluations on the (national) consumer ethnocentrism level (Hypothesis $\mathrm{H} 4$ ).

Hypothesis (H4). The importance attached to food attributes affects the consumer ethnocentrism level in the food market.

Food choice motives explain consumer behavior in the food market [29]. They are more relevant for food choices than values [30]. Qualitative research has shown that sensory quality, food safety, and environmental care influence domestic food choices [31]. Therefore, it is justified to study the impact of food choice motives on consumer ethnocentrism in the food market (Hypothesis H5).

Hypothesis (H5). Food choice motives affect the consumer ethnocentrism level in the food market.

Various differences in consumer attitudes and behaviors in the food market were observed across genders (see e.g., [32]). Kemmelmeier [33] argued that research on cognitive orientation and social beliefs should include gender differences to improve its scientific soundness. As differences in predictors of the willingness to pay a higher price for domestic food were observed between genders [34], it is justified to examine possible differences in the predictors of consumer ethnocentrism between men and women (Hypothesis H6).

Hypothesis (H6). Predictors of the consumer ethnocentrism level in the food market differ across genders.

\section{Materials and Methods}

\subsection{Research and Data Analysis Methods}

A self-administered online survey was conducted in a nationwide, representative sample of 1000 respondents aged 15 or more. The following representativeness criteria were selected: sex, the age structure in 10-year intervals, education level (primary, basic vocational, secondary, and tertiary), rural or urban location, and region. Moreover, we ensured a similar structure by age separately for men and women in 10-year intervals. An internet panel was used on the basis of quotas specified in the assumptions. In order to achieve a high level of representativeness of the sample, the survey was commissioned by the author's university in a public tender to a specialized market research agency. The survey was conducted in February 2020. The questionnaire was prepared by the author of this manuscript in consultation with other members of the research team. The respondents were made aware about the study objective and the anonymous scientific use of the collected empirical evidence was communicated.

In order to analyze the collected empirical material, Mann-Whitney U-tests, KruskalWallis H-tests, Spearman correlation coefficients, Pearson correlation matrixes, multiple regression models and retrograde stepwise regression models were applied. The risk of multicollinearity among the independent variables in the final regression models was examined with the use of correlation matrixes consisting of independent variables. The regression models contain standardized coefficients (denoted as $\beta$ ) and unstandardized 
coefficients (denoted as b). TIBCO Statistica Version 13.3 (TIBCO Software Inc., Palo Alto, CA, USA) was used to conduct statistical analyses.

\subsection{Operationalization of Key Variables}

Consumer ethnocentrism in the food market was measured with the use of the CETSCALE. The abbreviated 10-item version was chosen (e.g., [35], p. 100), rather than the original 17-item scale developed by Shimp and Sharma [36]. The Polish translation of the items was used according to Nestorowicz and Kaniewska-Seba [37], which were adapted to the food product category. The answers were measured in 7-point scales with two anchors. The CETSCALE index was calculated as the sum of points selected for each question, so the possible range was 10 to 70 . The possible maximum was higher than in the study of Awdziej et al. [35], because here 7-point scales were used instead of 5-point scales, following the original 7-point version of the scale [36].

The framework proposed by Schwartz [38] was used to measure the value orientations of respondents. It encompasses 10 values: self-direction, power, security, hedonism, benevolence, achievement, stimulation, conformity, universalism, and tradition. The corresponding items for these values were based on the CBOS survey [39]. Six-point scales with textual labels were applied. The original version of the scale was chosen, because it was more practical, as it contained much fewer items; the current version of the PVQ-RR questionnaire contains 59 items in its Polish translation [40]. As the survey questionnaire contained many constructs, the use of this more recent, but much longer version of the scale in combination with other variables included in this study could lead to respondents fatigue, straightlining, and, paradoxically, lower quality of responses.

The pride of being Polish was measured with an item similar to a question in the European Values Study [41]. However, the respondents were asked about the pride of being a Pole, rather than a Polish citizen. Referring to the European Values Study [41], the level of identification of the respondents with various places was investigated: the town or city where the respondent lives, the region where they live, the home country (Poland), Europe, and the world as a whole. The answers were measured on 5-point scales with labels.

The respondents were asked to rank the importance of selected attributes of food products. This question was based on [42] (p. 299) and [43], but here the list of attributes was extended by: (1) traditional method of production, (2) distance covered by the food from the producer to the point of sale, and (3) organic certificate-items based on [44] (p. 88), and the attribute "area of origin" was changed into "country of origin" to avoid any misunderstandings between the country of origin and the region of origin. The extension of the original list of food attributes was due to the subject matter of this article, as consumer ethnocentrism could be related to these additional characteristics. The answers were measured on a 5-point ordinal scale with labels.

Food selection motives were examined with the use of the single-item Food Choice Questionnaire (FCQ) developed by Onwezen et al. [29]. With just 11 items, it provides an acceptable balance between practical needs (to make the survey respondent-friendly) and psychometric concerns. Seven-point Likert scales were used with anchors at both ends. The average score for each item was calculated.

In order to ensure that this work could be reproduced in future studies, the operationalization of all the variables used in the regression models is presented in Table A1 in Appendix A.

\subsection{Sample Characteristics}

The sample representativeness criteria were fulfilled in a satisfactory manner (Table 1). The structure of the sample was compared to the general population (Polish population aged 15 and more) [45]. 
Table 1. A comparison of the sample structure with the general population (\%).

\begin{tabular}{|c|c|c|c|}
\hline Variable & Categories & Sample & General Population \\
\hline \multirow[b]{2}{*}{ Sex } & Females & 52.2 & 52.2 \\
\hline & Males & 47.8 & 47.8 \\
\hline \multirow{5}{*}{ Age } & $15-24$ & 17.3 & 11.8 \\
\hline & $25-34$ & 19.0 & 16.7 \\
\hline & $35-44$ & 14.6 & 19.3 \\
\hline & $45-54$ & 16.2 & 15.0 \\
\hline & $55-64$ & 20.4 & 15.9 \\
\hline \multirow{16}{*}{ Region } & 65 and over & 12.5 & 21.4 \\
\hline & Dolnośląskie & 7.5 & 7.6 \\
\hline & Kujawsko-pomorskie & 5.5 & 5.4 \\
\hline & Lubelskie & 5.7 & 5.5 \\
\hline & Lubuskie & 2.7 & 2.6 \\
\hline & Łódzkie & 6.6 & 6.4 \\
\hline & Małopolskie & 8.8 & 8.9 \\
\hline & Mazowieckie & 13.8 & 14.1 \\
\hline & Opolskie & 2.5 & 2.6 \\
\hline & Podkarpackie & 5.4 & 5.5 \\
\hline & Podlaskie & 3.1 & 3.1 \\
\hline & Pomorskie & 6.0 & 6.1 \\
\hline & Śląskie & 11.9 & 11.8 \\
\hline & Świętokrzyskie & 3.3 & 3.2 \\
\hline & $\begin{array}{l}\text { Warmińsko- } \\
\text { mazurskie }\end{array}$ & 3.6 & 3.7 \\
\hline & Wielkopolskie & 9.0 & 9.1 \\
\hline \multirow{4}{*}{$\begin{array}{l}\text { Rural or Urban } \\
\text { Location }\end{array}$} & Zachodniopomorskie & 4.6 & 4.4 \\
\hline & Rural areas & 39.4 & 39.5 \\
\hline & Urban areas & 60.6 & 60.5 \\
\hline & Primary & 19.5 & 13.3 \\
\hline \multirow{3}{*}{ Education } & Basic vocational & 21.2 & 23.8 \\
\hline & Secondary & 32.4 & 34.7 \\
\hline & Tertiary & 26.9 & 28.2 \\
\hline
\end{tabular}

Note: the data for education in Poland are for the 15-64 age group; the data for the other variables concern the Polish population aged 15 and over.

\section{Results}

\subsection{Measuring Consumer Ethnocentrism with the CETSCALE}

As far as the CETSCALE is concerned, the highest agreement of respondents was observed for the following items: "Only those food products that are unavailable in Poland should be imported.", "We should buy from foreign countries only those food products that we cannot obtain within our own country.", "Polish food products, first, last, and foremost.", and "It may cost me in the long-run but I prefer to support Polish food products" (Table 2). The study participants exhibited the weakest identification with the following statements: "Purchasing foreign-made food products is un-Polish." and "Polish consumers who purchase food products made in other countries are responsible for putting their fellow Poles out of work.".

The statistical characteristics of the CETSCALE index in the sample were as follows: mean: 41.263 , standard deviation: 14.653 , variation: 0.355 , minimum: 10 , first quartile: 32 , median: 42 , third quartile: 51 , maximum: 70 , skewness: -0.121 , kurtosis: -0.510 . 
Table 2. Consumer ethnocentrism in the food market (10-item CETSCALE).

\begin{tabular}{lc}
\hline \multicolumn{1}{c}{ CETSCALE Item } & 1-7 Score \\
\hline $\begin{array}{l}\text { Only those food products that are unavailable } \\
\text { in Poland should be imported. }\end{array}$ & 4.558 \\
$\begin{array}{l}\text { Polish food products, first, last, and foremost. } \\
\text { Purchasing foreign-made food products is } \\
\text { un-Polish. }\end{array}$ & 4.481 \\
$\begin{array}{l}\text { It is not right to purchase foreign food, because } \\
\text { it puts Poles out of jobs. }\end{array}$ & 3.615 \\
$\begin{array}{l}\text { A real Pole should always buy Polish-made } \\
\text { food products. }\end{array}$ & 3.845 \\
$\begin{array}{l}\text { We should purchase food products } \\
\text { manufactured in Poland instead of letting } \\
\text { other countries get rich off us. }\end{array}$ & 3.855 \\
$\begin{array}{l}\text { Poles should not buy foreign food products, } \\
\text { because this hurts Polish business and causes } \\
\text { unemployment. }\end{array}$ & 4.361 \\
$\begin{array}{l}\text { It may cost me in the long-run, but I prefer to } \\
\text { support Polish food products. }\end{array}$ & 3.895 \\
$\begin{array}{l}\text { We should buy from foreign countries only } \\
\text { those food products that we cannot obtain } \\
\text { within our own country. }\end{array}$ & 4.464 \\
$\begin{array}{l}\text { Polish consumers who purchase food products } \\
\text { made in other countries are responsible for } \\
\text { putting their fellow Poles out of work. }\end{array}$ & 4.553 \\
\hline
\end{tabular}

\subsection{Bivariate Analyses of Consumer Ethnocentrism in the Food Market}

The level of consumer ethnocentrism was examined depending on various consumer characteristics in a series of bivariate nonparametric analyses. As far as sex is concerned, no significant difference was observed between men and women with the use of the MannWhitney U-test $(\mathrm{U}=122095, \mathrm{Z}=0.584, p=0.559)$. As for age, there was a significant differentiation of the CETSCALE index, indicated by the Kruskal-Wallis test $(\mathrm{H}=38.292$, $p<0.001)$. Figure 1 shows the median and quartile ranges of the CETSCALE index among six age intervals (15-24, 25-34, 35-44, 45-54, 55-64, and 65+). A nonlinear trend was observed. Consumer ethnocentrism grows with age until the late 30 s/early 40 s, then it starts to decline. It was clearly the lowest among the youngest respondents (15-24 years old). Multiple comparisons show that it was significantly lower than in the remaining age intervals (all $p$-values $<0.001$ ).

Consumer ethnocentrism in the food market depends on the composition of one's household. It grows with the number of members of one's household (Spearman correlation coefficient $\rho=0.098, p<0.01$ ) and with the number of children living with the respondent $(\rho=0.138, p<0.001)$.

Although consumer ethnocentrism declined with the size of the respondent's city, this differentiation failed to reach statistical significance (Kruskal-Wallis H-test $=4.350$, $p=0.226)$. Similarly, the comparison between urban and rural inhabitants demonstrated the lack of a significant difference with the use of the Mann-Whitney U-test $(\mathrm{U}=114840$, $\mathrm{Z}=-1.018, p=0.309$ ). The macro-region where the respondent lives also did not influence the CETSCALE level (the Kruskal-Wallis $\mathrm{H}=8.577, p=0.199$ ).

Moreover, the education level did not have a significant impact on consumer ethnocentrism (the Kruskal-Wallis $\mathrm{H}=2.110, p=0.550$ ). However, the CETSCALE level varied according to the professional activity of respondents (the Kruskal-Wallis $\mathrm{H}=25.822$, $p<0.001)$. It was significantly lower among students than white-collar workers $(p<0.001)$, blue-collar workers $(p<0.001)$, home carers $(p=0.003)$, and old-age and disability pensioners $(p<0.001)$. These differences may be partially explained by the younger age of students compared to the other socio-professional groups. Consumer ethnocentrism in the food market was not dependent on the income group to which the respondent belongs (the 
Kruskal-Wallis $\mathrm{H}=3.595, p=0.464$ ), but it was positively related to the level of satisfaction with the financial situation of one's family (Spearman correlation coefficient $\rho=0.111$, $p<0.001)$.

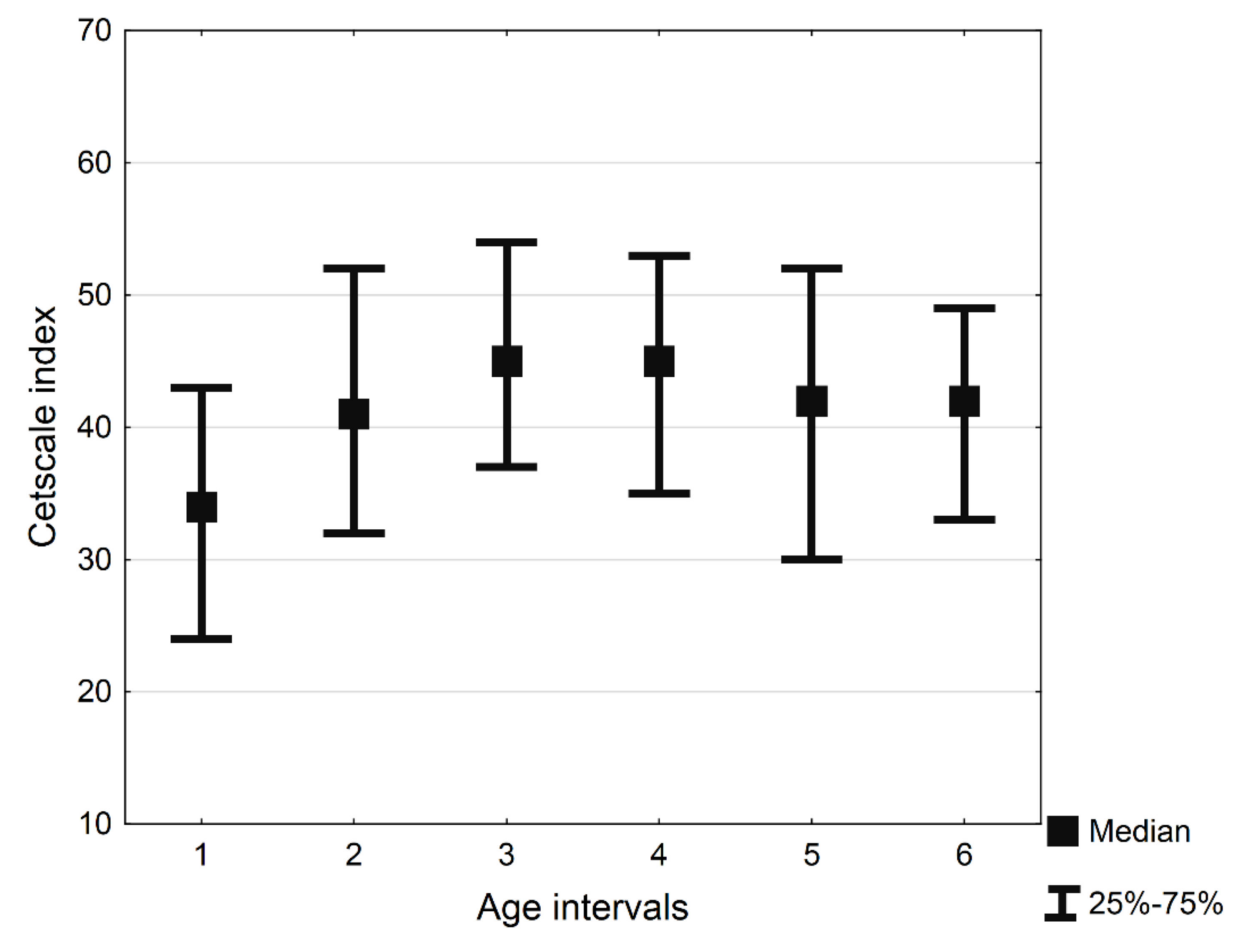

Figure 1. Consumer ethnocentrism in the food market in various age groups. Note: Age intervals: 1 . 15-24, 2. 25-34, 3. 35-44, 4. 45-54, 5. 55-64, and 6. 65+.

The length of time spent abroad during one's life did not affect significantly the level of consumer ethnocentrism in the food market (Kruskal-Wallis $\mathrm{H}=5.944, p=0.203$ ).

Consumer ethnocentrism in the food market was significantly correlated with the healthiness of one's diet (Spearman correlation coefficient $\rho=0.148, p<0.001$ ) and one's knowledge about healthy nutrition $(\rho=0.092, p<0.01)$ but not one's health status $(\rho=0.062$, $p>0.05)$. However, it is worth noting that all these variables were self-reported rather than observed, which may lead to some common method bias.

Consumer ethnocentrism in the food market was related to 5 out of 10 Schwartz values: tradition $(\rho=0.370, p<0.001)$, conformity $(\rho=0.205, p<0.001)$, universalism ( $\rho=0.162, p<0.001)$, benevolence $(\rho=0.110, p<0.001)$, and security $(\rho=0.092, p<0.01)$. The strongest correlation was observed with tradition.

Consumer ethnocentrism in the food market was not related to the regulatory focus. There were no significant correlations with the promotion orientation $(\rho=-0.036, p>0.05)$, prevention orientation $(\rho=0.022, p>0.05)$, or the predominant regulatory focus, calculated as the difference between promotion and prevention $(\rho=-0.032, p>0.05)$.

Consumer ethnocentrism in the food market was related to the level of satisfaction with one's life $(\rho=0.151, p<0.001)$, self-efficacy $(\rho=0.129, p<0.001)$, trust $(\rho=0.089$, $p<0.01)$, and being proud of being Polish $(\rho=0.332, p<0.001)$.

It was correlated with consumer feelings of being connected with certain places. Unsurprisingly, it was related to feeling connected with one's home country $(\rho=0.282$, $p<0.001)$, but there were also positive correlations with the identification with one's town, city $(\rho=0.200, p<0.001)$, or region $(\rho=0.253, p<0.001)$. It was not related to one's identification with Europe $(\rho=0.017, p>0.05)$ or the world as a whole $(\rho=-0.020$, $p>0.05)$.

Consumer ethnocentrism in the food market was significantly correlated with the importance attached to all investigated food attributes except price $(\rho=0.037, p>0.05)$. 
The strongest correlations were observed with the importance attached to the country of origin of the food product $(\rho=0.317, p<0.001)$, the distance covered by the food from the producer to the shop $(\rho=0.275, p<0.001)$, and the traditional method of production $(\rho=0.271, p<0.001)$.

Consumer ethnocentrism in the food market was correlated with all food choice motives included in the single-item Food Choice Questionnaire. The strongest correlations were observed for natural content $(\rho=0.284, p<0.001)$, environmental friendliness $(\rho=0.282, p<0.001)$, and fair trade $(\rho=0.267, p<0.001)$.

Consumer ethnocentrism in the food market did not depend on the level of consumer knowledge about the countries of origin of selected food brands, which was examined in three ways: (1) as the distinction between Polish and foreign operations $(\rho=-0.023$, $p>0.05)$, (2) as the distinction between Polish and foreign ownership $(\rho=-0.049, p>0.05)$, and 3) as the number of correct indications of the country of origin of the brand owners $(\rho=0.027, p>0.05)$.

\subsection{Predictors of Consumer Ethnocentrism in the Food Market in the Whole Sample}

Variables which were significantly related to the CETSCALE level in bivariate analyses were included in a multiple regression model in order to examine their simultaneous impact on consumer ethnocentrism in the food market (Table 3). The regression model had 38 independent variables, 14 out of which turned out to be significant predictors of the dependent variable (at the level of $p<0.05$ ). In this full model, consumer ethnocentrism was positively related to the conformity and tradition Schwartz values, pride of being Polish, country of origin as a food attribute, importance attached to the distance covered by food from the producer to the consumer, and convenience, as well as natural content, environmental friendliness, and fair trade as food choice motives. It was negatively related to being a student, the benevolence and universalism Schwartz values, and sensory appeal and animal friendliness as food choice criteria. The whole model was statistically significant $(\mathrm{F}=13.009, p<0.001)$ and explained $31 \%$ of the variance of the dependent variable (adjusted $\left.\mathrm{R}^{2}=0.314\right)$.

Table 3. Selected predictors of consumer ethnocentrism in the food market (a multiple regression model).

\begin{tabular}{|c|c|c|c|c|c|c|}
\hline Predictor & $\beta$ & $\operatorname{SE}(\beta)$ & $\mathbf{b}$ & $\mathrm{SE}(\mathbf{b})$ & $t(961)$ & $p$ \\
\hline Intercept & $\mathrm{x}$ & $\mathrm{x}$ & -0.990 & 3.887 & -0.255 & 0.799 \\
\hline Age (15-24) & -0.035 & 0.032 & -1.547 & 1.403 & -1.102 & 0.271 \\
\hline Household size & 0.074 & 0.039 & 0.899 & 0.474 & 1.894 & 0.059 \\
\hline Number of children & -0.028 & 0.040 & -0.436 & 0.615 & -0.709 & 0.479 \\
\hline Student & -0.083 & 0.031 & -5.935 & 2.221 & -2.672 & 0.008 \\
\hline $\begin{array}{l}\text { Satisfaction with the } \\
\text { financial situation }\end{array}$ & -0.017 & 0.035 & -0.118 & 0.250 & -0.473 & 0.636 \\
\hline Diet health & 0.015 & 0.033 & 0.311 & 0.690 & 0.451 & 0.652 \\
\hline $\begin{array}{l}\text { Knowledge about } \\
\text { healthy nutrition }\end{array}$ & -0.014 & 0.032 & -0.272 & 0.633 & -0.430 & 0.667 \\
\hline Security & 0.015 & 0.029 & 0.189 & 0.367 & 0.515 & 0.607 \\
\hline Benevolence & -0.068 & 0.031 & -0.964 & 0.438 & -2.204 & 0.028 \\
\hline Conformity & 0.096 & 0.030 & 1.212 & 0.378 & 3.202 & 0.001 \\
\hline Universalism & -0.091 & 0.034 & -1.262 & 0.476 & -2.649 & 0.008 \\
\hline Tradition & 0.222 & 0.032 & 2.373 & 0.345 & 6.868 & 0.000 \\
\hline Satisfaction with life & 0.071 & 0.038 & 0.524 & 0.284 & 1.847 & 0.065 \\
\hline Self-efficacy & -0.024 & 0.038 & -0.172 & 0.279 & -0.618 & 0.537 \\
\hline
\end{tabular}


Table 3. Cont.

\begin{tabular}{|c|c|c|c|c|c|c|}
\hline Predictor & $\beta$ & $\operatorname{SE}(\beta)$ & b & $\mathrm{SE}(\mathrm{b})$ & $t(961)$ & $p$ \\
\hline Trust & 0.000 & 0.028 & 0.002 & 0.378 & 0.004 & 0.996 \\
\hline $\begin{array}{l}\text { Pride of being } \\
\text { Polish }\end{array}$ & 0.153 & 0.039 & 2.332 & 0.586 & 3.977 & 0.000 \\
\hline $\begin{array}{l}\text { Connection with } \\
\text { town or city }\end{array}$ & 0.011 & 0.037 & 0.158 & 0.519 & 0.303 & 0.762 \\
\hline $\begin{array}{l}\text { Connection with } \\
\text { region }\end{array}$ & 0.011 & 0.040 & 0.164 & 0.604 & 0.272 & 0.786 \\
\hline $\begin{array}{l}\text { Connection with } \\
\text { Poland }\end{array}$ & 0.037 & 0.041 & 0.560 & 0.621 & 0.902 & 0.367 \\
\hline $\begin{array}{l}\text { Country of origin as } \\
\text { a food attribute }\end{array}$ & 0.120 & 0.033 & 1.712 & 0.475 & 3.607 & 0.000 \\
\hline Quality signs & -0.009 & 0.033 & -0.138 & 0.530 & -0.261 & 0.794 \\
\hline Brand & -0.036 & 0.032 & -0.561 & 0.491 & -1.144 & 0.253 \\
\hline Retailer trust & -0.049 & 0.032 & -0.798 & 0.523 & -1.524 & 0.128 \\
\hline Product appearance & -0.032 & 0.031 & -0.508 & 0.493 & -1.031 & 0.303 \\
\hline $\begin{array}{l}\text { Traditional method } \\
\text { of production }\end{array}$ & 0.021 & 0.037 & 0.330 & 0.569 & 0.579 & 0.562 \\
\hline Distance covered & 0.120 & 0.034 & 1.579 & 0.448 & 3.522 & 0.000 \\
\hline Organic certificate & -0.007 & 0.037 & -0.087 & 0.482 & -0.180 & 0.858 \\
\hline $\begin{array}{l}\text { Health as a food } \\
\text { choice motive }\end{array}$ & 0.025 & 0.036 & 0.261 & 0.376 & 0.694 & 0.488 \\
\hline Mood & 0.037 & 0.032 & 0.365 & 0.310 & 1.176 & 0.240 \\
\hline Convenience & 0.084 & 0.034 & 0.930 & 0.375 & 2.482 & 0.013 \\
\hline Sensory appeal & -0.090 & 0.035 & -1.018 & 0.402 & -2.529 & 0.012 \\
\hline Natural content & 0.093 & 0.039 & 1.002 & 0.421 & 2.381 & 0.017 \\
\hline Price & -0.010 & 0.034 & -0.110 & 0.386 & -0.284 & 0.777 \\
\hline Weight control & 0.039 & 0.033 & 0.348 & 0.295 & 1.180 & 0.238 \\
\hline Familiarity & 0.020 & 0.033 & 0.216 & 0.362 & 0.595 & 0.552 \\
\hline $\begin{array}{l}\text { Environmental } \\
\text { friendliness }\end{array}$ & 0.113 & 0.049 & 1.090 & 0.467 & 2.334 & 0.020 \\
\hline Animal friendliness & -0.131 & 0.049 & -1.192 & 0.449 & -2.652 & 0.008 \\
\hline Fair trade & 0.106 & 0.043 & 1.011 & 0.411 & 2.462 & 0.014 \\
\hline
\end{tabular}

Note: $\beta$ denotes standardized regression coefficients, $\mathrm{b}$ denotes unstandardized regression coefficients.

However, as the model was rather complex, a more parsimonious way to predict consumer ethnocentrism in the food market was needed. That is why the retrograde stepwise regression was applied. In this modified model, only eight predictors remained (Table 4). All of them were highly significant, and the entire model was also statistically significant $(\mathrm{F}=52.386, p<0.001)$. The model explained over $29 \%$ of the variance of the dependent variable (adjusted $\mathrm{R}^{2}=0.292$ ), so the elimination of 30 variables from the previous model led to a decrease in the explanatory power of only 2.2 percentage points. In this final model, the CETSCALE level turned out to be positively related to the respondents conformity and tradition, to the pride of being Polish, to the importance attached to the country of origin, and distance covered by food products, and to the natural content as a food choice motive. It was negatively related to being a student and to the universalism Schwartz value.

Therefore, Hypothesis H1 was partly confirmed, with only one sociodemographic characteristic influencing the CETSCALE index (being a student). Hypothesis H2 was accepted, as three Schwartz values affected the level of consumer ethnocentrism in the food market. Regarding Hypothesis H3, only one additional psychographic characteristic (the pride of being Polish) was found to have an impact on consumer ethnocentrism in the food market. The Hypothesis H4 was accepted, as two food attributes (importance attached to the country of origin and to the distance covered by the food product) affected the level of consumer ethnocentrism in the food market. As far as the Hypothesis H5 is concerned, one food choice motive (natural content) was found to influence consumer ethnocentrism in the food market. 
Table 4. Selected predictors of consumer ethnocentrism in the food market (a retrograde stepwise regression model).

\begin{tabular}{|c|c|c|c|c|c|c|}
\hline Predictor & $\beta$ & $\operatorname{SE}(\beta)$ & b & SE(b) & $\mathbf{t}(991)$ & $p$ \\
\hline Intercept & $x$ & $x$ & 0.042 & 2.616 & 0.016 & 0.987 \\
\hline Student & -0.093 & 0.027 & -6.670 & 1.922 & -3.470 & 0.001 \\
\hline Conformity & 0.093 & 0.029 & 1.179 & 0.371 & 3.178 & 0.002 \\
\hline Universalism & -0.113 & 0.031 & -1.576 & 0.432 & -3.649 & 0.000 \\
\hline Tradition & 0.231 & 0.031 & 2.464 & 0.335 & 7.345 & 0.000 \\
\hline Pride of being Polish & 0.182 & 0.029 & 2.776 & 0.446 & 6.227 & 0.000 \\
\hline $\begin{array}{l}\text { Country of origin as a } \\
\text { food attribute }\end{array}$ & 0.131 & 0.031 & 1.862 & 0.442 & 4.210 & 0.000 \\
\hline $\begin{array}{l}\text { Distance covered as a } \\
\text { food attribute }\end{array}$ & 0.146 & 0.030 & 1.921 & 0.395 & 4.864 & 0.000 \\
\hline $\begin{array}{l}\text { Natural content as a } \\
\text { food choice motive }\end{array}$ & 0.149 & 0.030 & 1.609 & 0.323 & 4.979 & 0.000 \\
\hline
\end{tabular}

Note: $\beta$ denotes standardized regression coefficients, $\mathrm{b}$ denotes unstandardized regression coefficients.

In order to examine potential problems with multicollinearity and the relations among the predictors, a correlation matrix was constructed with independent variables used in the retrograde stepwise regression in the total sample (Table 5). The strongest correlations were observed between country of origin as a food attribute and distance covered as a food attribute $(r=0.428)$, between tradition and pride of being Polish $(r=0.380)$, and between universalism and natural content as a food choice motive $(r=0.367)$. As all the correlations were weak or moderate, the risk of multicollinearity was considered as low. Therefore, the above regression model is acceptable.

Table 5. Correlation matrix for predictors of consumer ethnocentrism in the food market used in the retrograde stepwise regression model in the total sample.

\begin{tabular}{|c|c|c|c|c|c|c|c|c|}
\hline $\begin{array}{l}\text { Variable } \\
\text { No. }\end{array}$ & Variable & 1. & 2. & 3. & 4. & 5. & 6. & 7. \\
\hline 1. & Student & & & & & & & \\
\hline 2. & Conformity & $\begin{array}{l}-0.046 \\
(0.146)\end{array}$ & & & & & & \\
\hline 3. & Universalism & $\begin{array}{l}-0.049 \\
(0.119)\end{array}$ & $\begin{array}{c}0.336 \\
(0.000)\end{array}$ & & & & & \\
\hline 4. & Tradition & $\begin{array}{l}-0.090 \\
(0.004)\end{array}$ & $\begin{array}{c}0.344 \\
(0.000)\end{array}$ & $\begin{array}{c}0.321 \\
(0.000)\end{array}$ & & & & \\
\hline 5. & Pride of being Polish & $\begin{array}{l}-0.054 \\
(0.089)\end{array}$ & $\begin{array}{c}0.130 \\
(0.000)\end{array}$ & $\begin{array}{c}0.197 \\
(0.000)\end{array}$ & $\begin{array}{c}0.380 \\
(0.000)\end{array}$ & & & \\
\hline 6. & $\begin{array}{l}\text { Country of origin as a } \\
\text { food attribute }\end{array}$ & $\begin{array}{l}-0.026 \\
(0.411)\end{array}$ & $\begin{array}{c}0.115 \\
(0.000)\end{array}$ & $\begin{array}{c}0.265 \\
(0.000)\end{array}$ & $\begin{array}{c}0.267 \\
(0.000)\end{array}$ & $\begin{array}{c}0.216 \\
(0.000)\end{array}$ & & \\
\hline 7. & $\begin{array}{l}\text { Distance covered as a } \\
\text { food attribute }\end{array}$ & $\begin{array}{l}-0.070 \\
(0.027)\end{array}$ & $\begin{array}{c}0.109 \\
(0.001)\end{array}$ & $\begin{array}{c}0.237 \\
(0.000)\end{array}$ & $\begin{array}{c}0.185 \\
(0.000)\end{array}$ & $\begin{array}{c}0.109 \\
(0.001)\end{array}$ & $\begin{array}{l}0.428 \\
(0.000)\end{array}$ & \\
\hline 8. & $\begin{array}{l}\text { Natural content as a } \\
\text { food choice motive }\end{array}$ & $\begin{array}{l}-0.116 \\
(0.000)\end{array}$ & $\begin{array}{c}0.121 \\
(0.000)\end{array}$ & $\begin{array}{c}0.367 \\
(0.000)\end{array}$ & $\begin{array}{c}0.184 \\
(0.000)\end{array}$ & $\begin{array}{c}0.208 \\
(0.000)\end{array}$ & $\begin{array}{c}0.315 \\
(0.000)\end{array}$ & $\begin{array}{c}0.253 \\
(0.000)\end{array}$ \\
\hline
\end{tabular}

Note: The table contains Pearson correlation coefficients and $p$-values in parentheses.

\subsection{Predictors of Consumer Ethnocentrism in the Food Market among Men}

In order to explore potential differences in predictors of consumer ethnocentrism between men and women, separate regression models for both genders were constructed. First, a multiple regression model was developed for men (Table 6) with the use of the same variables as in the full model used in the total sample. This rather complex model explained $36 \%$ of the variation of the dependent variable (adjusted $R^{2}=0.363$ ) and was statistically significant $(\mathrm{F}=8.148, p<0.001)$. Consumer ethnocentrism in the food market among men was positively associated with environmental friendliness as a food choice 
motive, pride of being Polish, the tradition Schwartz value, distance covered as a food attribute, satisfaction with one's life, the conformity Schwartz value, natural content as a food choice motive, and country of origin as a food attribute. It was negatively associated with animal friendliness as a food choice motive, the universalism Schwartz value, and sensory appeal as a food choice motive.

Table 6. Selected predictors of consumer ethnocentrism in the food market among men (a multiple regression model).

\begin{tabular}{|c|c|c|c|c|c|c|}
\hline Predictor & B & $\operatorname{SE}(\beta)$ & $\mathbf{b}$ & SE(b) & $t(439)$ & $p$ \\
\hline Intercept & $x$ & $x$ & -1.269 & 5.360 & -0.237 & 0.813 \\
\hline Age (15-24) & -0.018 & 0.042 & -0.752 & 1.805 & -0.416 & 0.677 \\
\hline Household size & 0.032 & 0.055 & 0.379 & 0.654 & 0.579 & 0.563 \\
\hline Number of children & 0.023 & 0.055 & 0.358 & 0.853 & 0.420 & 0.675 \\
\hline Student & -0.052 & 0.042 & -3.954 & 3.216 & -1.230 & 0.219 \\
\hline $\begin{array}{l}\text { Satisfaction with the financial } \\
\text { situation }\end{array}$ & -0.026 & 0.049 & -0.198 & 0.365 & -0.543 & 0.587 \\
\hline Diet health & 0.024 & 0.049 & 0.487 & 0.988 & 0.493 & 0.622 \\
\hline Knowledge about healthy nutrition & -0.047 & 0.044 & -0.924 & 0.867 & -1.066 & 0.287 \\
\hline Security & 0.049 & 0.041 & 0.626 & 0.523 & 1.197 & 0.232 \\
\hline Benevolence & -0.078 & 0.042 & -1.111 & 0.600 & -1.852 & 0.065 \\
\hline Conformity & 0.136 & 0.043 & 1.773 & 0.563 & 3.147 & 0.002 \\
\hline Universalism & -0.124 & 0.049 & -1.665 & 0.660 & -2.523 & 0.012 \\
\hline Tradition & 0.237 & 0.046 & 2.546 & 0.496 & 5.135 & 0.000 \\
\hline Satisfaction with life & 0.138 & 0.055 & 1.022 & 0.406 & 2.516 & 0.012 \\
\hline Self-efficacy & -0.076 & 0.054 & -0.565 & 0.400 & -1.414 & 0.158 \\
\hline Trust & -0.017 & 0.041 & -0.226 & 0.554 & -0.408 & 0.684 \\
\hline Pride of being Polish & 0.208 & 0.057 & 3.081 & 0.844 & 3.652 & 0.000 \\
\hline Connection with town or city & -0.021 & 0.054 & -0.292 & 0.748 & -0.391 & 0.696 \\
\hline Connection with region & 0.024 & 0.058 & 0.347 & 0.848 & 0.409 & 0.683 \\
\hline Connection with Poland & 0.010 & 0.059 & 0.149 & 0.867 & 0.171 & 0.864 \\
\hline Country of origin as a food attribute & 0.097 & 0.049 & 1.337 & 0.677 & 1.976 & 0.049 \\
\hline Quality signs & -0.034 & 0.045 & -0.528 & 0.710 & -0.744 & 0.457 \\
\hline Brand & -0.002 & 0.046 & -0.031 & 0.679 & -0.046 & 0.963 \\
\hline Retailer trust & -0.081 & 0.046 & -1.296 & 0.725 & -1.787 & 0.075 \\
\hline Product appearance & -0.059 & 0.043 & -0.931 & 0.678 & -1.373 & 0.170 \\
\hline Traditional method of production & 0.014 & 0.053 & 0.212 & 0.819 & 0.259 & 0.795 \\
\hline Distance covered & 0.152 & 0.049 & 1.959 & 0.628 & 3.119 & 0.002 \\
\hline Organic certificate & -0.017 & 0.052 & -0.213 & 0.659 & -0.324 & 0.746 \\
\hline Health as a food choice motive & 0.026 & 0.052 & 0.265 & 0.518 & 0.511 & 0.609 \\
\hline Mood & 0.069 & 0.045 & 0.687 & 0.450 & 1.527 & 0.127 \\
\hline Convenience & 0.052 & 0.049 & 0.589 & 0.549 & 1.072 & 0.284 \\
\hline Sensory appeal & -0.115 & 0.048 & -1.310 & 0.547 & -2.395 & 0.017 \\
\hline Natural content & 0.115 & 0.056 & 1.227 & 0.594 & 2.065 & 0.040 \\
\hline Price & -0.005 & 0.049 & -0.060 & 0.564 & -0.106 & 0.916 \\
\hline Weight control & 0.048 & 0.048 & 0.423 & 0.425 & 0.997 & 0.319 \\
\hline Familiarity & 0.026 & 0.047 & 0.295 & 0.533 & 0.553 & 0.580 \\
\hline Environmental friendliness & 0.281 & 0.070 & 2.669 & 0.666 & 4.005 & 0.000 \\
\hline Animal friendliness & -0.189 & 0.071 & -1.670 & 0.623 & -2.680 & 0.008 \\
\hline Fair trade & 0.082 & 0.059 & 0.774 & 0.555 & 1.394 & 0.164 \\
\hline
\end{tabular}

Note: $\beta$ denotes standardized regression coefficients, $b$ denotes unstandardized regression coefficients.

In order to obtain a more specific model, retrograde stepwise regression was applied among men (Table 7). The model explained almost 30\% of the variation of the CETSCALE index (adjusted $\left.R^{2}=0.298\right)$ and was statistically significant $(F=51.697, p<0.001)$. According to this model, consumer ethnocentrism in the food market among men was positively related to the tradition Schwartz value, environmental friendliness as a food choice motive, pride of being Polish, and distance covered as a food attribute. 
Table 7. Selected predictors of consumer ethnocentrism in the food market among men (a retrograde stepwise regression model).

\begin{tabular}{ccccccc}
\hline Predictor & $\boldsymbol{\beta}$ & $\mathrm{SE}(\boldsymbol{\beta})$ & $\mathrm{B}$ & $\mathrm{SE}(\mathbf{b})$ & $\mathbf{t}(\mathbf{4 7 3})$ & $p$ \\
\hline Intercept & $\mathrm{x}$ & $\mathrm{x}$ & 0.115 & 3.003 & 0.038 & 0.969 \\
Tradition & $\mathbf{0 . 2 6 1}$ & $\mathbf{0 . 0 4 2}$ & $\mathbf{2 . 8 0 8}$ & $\mathbf{0 . 4 5 7}$ & $\mathbf{6 . 1 4 1}$ & $\mathbf{0 . 0 0 0}$ \\
Pride of being Polish & $\mathbf{0 . 1 9 4}$ & $\mathbf{0 . 0 4 2}$ & $\mathbf{2 . 8 7 4}$ & $\mathbf{0 . 6 1 9}$ & $\mathbf{4 . 6 4 4}$ & $\mathbf{0 . 0 0 0}$ \\
Distance covered as a food & $\mathbf{0 . 1 4 9}$ & $\mathbf{0 . 0 4 2}$ & $\mathbf{1 . 9 1 9}$ & $\mathbf{0 . 5 3 5}$ & $\mathbf{3 . 5 8 5}$ & $\mathbf{0 . 0 0 0}$ \\
attribute & $\mathbf{0 . 2 3 5}$ & $\mathbf{0 . 0 4 1}$ & $\mathbf{2 . 2 3 4}$ & $\mathbf{0 . 3 9 4}$ & $\mathbf{5 . 6 7 6}$ & $\mathbf{0 . 0 0 0}$
\end{tabular}

Note: $\beta$ denotes standardized regression coefficients, $\mathrm{b}$ denotes unstandardized regression coefficients.

In order to examine potential problems with multicollinearity and relations among the predictors, a correlation matrix was constructed with independent variables used in the retrograde stepwise regression among men (Table 8). The strongest correlations were observed between tradition and pride of being Polish $(\mathrm{r}=0.393)$ and between distance covered as a food attribute and environmental friendliness as a food choice motive $(r=0.361)$. As all the correlations were weak or moderate, the risk of multicollinearity was considered as low. Therefore, the above regression model is acceptable.

Table 8. Correlation matrix for predictors of consumer ethnocentrism in the food market used in the retrograde stepwise regression model among men.

\begin{tabular}{|c|c|c|c|c|}
\hline Variable No. & Variable & 1. & 2. & 3. \\
\hline 1. & Tradition & & & \\
\hline 2. & Pride of being Polish & $\begin{array}{c}0.393 \\
(0.000)\end{array}$ & & \\
\hline 3. & $\begin{array}{l}\text { Distance covered as a food } \\
\text { attribute }\end{array}$ & $\begin{array}{c}0.205 \\
(0.000)\end{array}$ & $\begin{array}{c}0.104 \\
(0.023)\end{array}$ & \\
\hline 4. & Environmental friendliness & $\begin{array}{c}0.172 \\
(0.000)\end{array}$ & $\begin{array}{c}0.136 \\
(0.003)\end{array}$ & $\begin{array}{c}0.361 \\
(0.000)\end{array}$ \\
\hline
\end{tabular}

Note: The table contains Pearson correlation coefficients and $p$-values in parentheses.

\subsection{Predictors of Consumer Ethnocentrism in the Food Market among Women}

Analogous to the previous model, a multiple regression model was constructed with the same independent variables for women (Table 9). This full model explained $26 \%$ of the variation of the dependent variable (adjusted $R^{2}=0.261$ ) and was statistically significant $(\mathrm{F}=5.846, p<0.001)$. Consumer ethnocentrism in the food market among women was positively associated with the tradition Schwartz value, household size, country of origin as a food attribute, distance covered as a food attribute, pride of being Polish, and convenience as a food choice motive.

In order to arrive at a more specific model, retrograde stepwise regression modelling was applied (Table 10). This simpler model had almost the same level of explanatory power as the full model (adjusted $\mathrm{R}^{2}=0.253$ ) and was statistically significant $(\mathrm{F}=36.344$, $p<0.001)$. Consumer ethnocentrism in the food market among women was determined by age, the tradition value, pride of being Polish, importance attached to the country of origin as a food attribute, and importance attached to the distance covered by the food product from the producer to the consumer. The strongest predictors were tradition and pride of being Polish $(\beta>0.2)$. All the independent variables contributed positively to consumer ethnocentrism with the exception of being in the youngest age group. The Hypothesis H6 was accepted as predictors of consumer ethnocentrism in the food market differed between genders, which is visible in comparing Tables 7 and 10. 
Table 9. Selected predictors of consumer ethnocentrism in the food market among women (a multiple regression model).

\begin{tabular}{|c|c|c|c|c|c|c|}
\hline Predictor & B & $\operatorname{SE}(\beta)$ & $\mathbf{b}$ & SE(b) & $t(483)$ & $p$ \\
\hline Intercept & $x$ & $x$ & -3.013 & 5.881 & -0.512 & 0.609 \\
\hline Age (15-24) & -0.070 & 0.050 & -3.182 & 2.308 & -1.379 & 0.169 \\
\hline Household size & 0.130 & 0.058 & 1.588 & 0.712 & 2.230 & 0.026 \\
\hline Number of children & -0.083 & 0.059 & -1.300 & 0.915 & -1.422 & 0.156 \\
\hline Student & -0.087 & 0.049 & -5.856 & 3.307 & -1.771 & 0.077 \\
\hline Satisfaction with the financial situation & -0.016 & 0.053 & -0.107 & 0.360 & -0.296 & 0.767 \\
\hline Diet health & -0.015 & 0.048 & -0.326 & 1.025 & -0.318 & 0.750 \\
\hline Knowledge about healthy nutrition & 0.043 & 0.050 & 0.851 & 0.986 & 0.863 & 0.388 \\
\hline Security & -0.019 & 0.042 & -0.240 & 0.530 & -0.454 & 0.650 \\
\hline Benevolence & -0.046 & 0.046 & -0.653 & 0.660 & -0.990 & 0.323 \\
\hline Conformity & 0.063 & 0.044 & 0.775 & 0.534 & 1.450 & 0.148 \\
\hline Universalism & -0.093 & 0.050 & -1.345 & 0.718 & -1.873 & 0.062 \\
\hline Tradition & 0.211 & 0.048 & 2.243 & 0.506 & 4.434 & 0.000 \\
\hline Satisfaction with life & 0.014 & 0.057 & 0.101 & 0.421 & 0.240 & 0.810 \\
\hline Self-efficacy & 0.040 & 0.057 & 0.287 & 0.411 & 0.698 & 0.485 \\
\hline Trust & 0.025 & 0.040 & 0.333 & 0.542 & 0.614 & 0.539 \\
\hline Pride of being Polish & 0.119 & 0.055 & 1.871 & 0.865 & 2.163 & 0.031 \\
\hline Connection with town or city & 0.043 & 0.054 & 0.612 & 0.766 & 0.799 & 0.425 \\
\hline Connection with region & 0.009 & 0.058 & 0.132 & 0.896 & 0.148 & 0.883 \\
\hline Connection with Poland & 0.050 & 0.058 & 0.812 & 0.933 & 0.870 & 0.385 \\
\hline Country of origin as a food attribute & 0.126 & 0.048 & 1.851 & 0.701 & 2.641 & 0.009 \\
\hline Quality signs & -0.007 & 0.049 & -0.116 & 0.827 & -0.140 & 0.889 \\
\hline Brand & -0.061 & 0.046 & -0.991 & 0.737 & -1.345 & 0.179 \\
\hline Retailer trust & -0.023 & 0.046 & -0.390 & 0.783 & -0.498 & 0.619 \\
\hline Product appearance & 0.009 & 0.044 & 0.148 & 0.745 & 0.199 & 0.843 \\
\hline Traditional method of production & 0.036 & 0.055 & 0.557 & 0.841 & 0.662 & 0.508 \\
\hline Distance covered & 0.124 & 0.050 & 1.682 & 0.673 & 2.500 & 0.013 \\
\hline Organic certificate & -0.009 & 0.054 & -0.118 & 0.732 & -0.161 & 0.872 \\
\hline Health as a food choice motive & 0.037 & 0.051 & 0.412 & 0.572 & 0.720 & 0.472 \\
\hline Mood & 0.024 & 0.047 & 0.232 & 0.453 & 0.511 & 0.610 \\
\hline Convenience & 0.109 & 0.050 & 1.189 & 0.544 & 2.186 & 0.029 \\
\hline Sensory appeal & -0.078 & 0.055 & -0.893 & 0.621 & -1.438 & 0.151 \\
\hline Natural content & 0.078 & 0.058 & 0.847 & 0.628 & 1.349 & 0.178 \\
\hline Price & -0.004 & 0.049 & -0.043 & 0.548 & -0.079 & 0.937 \\
\hline Weight control & 0.015 & 0.049 & 0.131 & 0.433 & 0.304 & 0.762 \\
\hline Familiarity & 0.022 & 0.049 & 0.229 & 0.519 & 0.442 & 0.659 \\
\hline Environmental friendliness & -0.034 & 0.071 & -0.330 & 0.690 & -0.479 & 0.633 \\
\hline Animal friendliness & -0.106 & 0.073 & -1.004 & 0.694 & -1.447 & 0.148 \\
\hline Fair trade & 0.126 & 0.066 & 1.212 & 0.642 & 1.889 & 0.059 \\
\hline
\end{tabular}

Note: $\beta$ denotes standardized regression coefficients, $\mathrm{b}$ denotes unstandardized regression coefficients.

Table 10. Selected predictors of consumer ethnocentrism in the food market among women (a retrograde stepwise regression model).

\begin{tabular}{ccccccc}
\hline Predictor & $\beta$ & $\mathrm{SE}(\beta)$ & $\mathbf{b}$ & $\mathrm{SE}(\mathbf{b})$ & $\mathbf{t}(\mathbf{5 1 6})$ & $p$ \\
\hline Intercept & $\mathrm{x}$ & $\mathrm{x}$ & 4.563 & 3.223 & 1.416 & 0.157 \\
Age (15-24) & $\mathbf{- 0 . 1 2 6}$ & $\mathbf{0 . 0 3 9}$ & -5.761 & $\mathbf{1 . 7 6 5}$ & -3.263 & $\mathbf{0 . 0 0 1}$ \\
Tradition & $\mathbf{0 . 2 3 0}$ & $\mathbf{0 . 0 4 2}$ & $\mathbf{2 . 4 3 9}$ & $\mathbf{0 . 4 4 4}$ & $\mathbf{5 . 4 9 1}$ & $\mathbf{0 . 0 0 0}$ \\
Pride of being Polish & $\mathbf{0 . 2 0 4}$ & $\mathbf{0 . 0 4 1}$ & $\mathbf{3 . 1 9 8}$ & $\mathbf{0 . 6 4 4}$ & $\mathbf{4 . 9 6 5}$ & $\mathbf{0 . 0 0 0}$ \\
$\begin{array}{c}\text { Country of origin as a } \\
\text { food attribute }\end{array}$ & $\mathbf{0 . 1 3 5}$ & $\mathbf{0 . 0 4 2}$ & $\mathbf{1 . 9 8 0}$ & $\mathbf{0 . 6 1 8}$ & $\mathbf{3 . 2 0 5}$ & $\mathbf{0 . 0 0 1}$ \\
$\begin{array}{c}\text { Distance covered as a } \\
\text { food attribute }\end{array}$ & $\mathbf{0 . 1 4 7}$ & $\mathbf{0 . 0 4 1}$ & $\mathbf{1 . 9 9 5}$ & $\mathbf{0 . 5 6 1}$ & $\mathbf{3 . 5 5 8}$ & $\mathbf{0 . 0 0 0}$ \\
\hline
\end{tabular}

Note: $\beta$ denotes standardized regression coefficients, $\mathrm{b}$ denotes unstandardized regression coefficients.

In order to examine potential problems with multicollinearity and relations among the predictors, a correlation matrix was constructed with independent variables used in 
the retrograde stepwise regression among women (Table 11). The strongest correlations were observed between country of origin as a food attribute and distance covered as a food attribute $(\mathrm{r}=0.386)$ and between tradition and pride of being Polish $(\mathrm{r}=0.368)$. As all the correlations were weak or moderate, the risk of multicollinearity was considered as low. Therefore, the above regression model is acceptable.

Table 11. Correlation matrix for predictors of consumer ethnocentrism in the food market used in the retrograde stepwise regression model among women.

\begin{tabular}{|c|c|c|c|c|c|}
\hline Variable No. & Variable & 1. & 2. & 3. & 4. \\
\hline 1. & Age (15-24) & & & & \\
\hline 2. & Tradition & $\begin{array}{l}-0.164 \\
(0.000)\end{array}$ & & & \\
\hline 3. & Pride of being Polish & $\begin{array}{l}-0.024 \\
(0.584)\end{array}$ & $\begin{array}{c}0.368 \\
(0.000)\end{array}$ & & \\
\hline 4. & $\begin{array}{c}\text { Country of origin as a food } \\
\text { attribute }\end{array}$ & $\begin{array}{l}-0.070 \\
(0.109)\end{array}$ & $\begin{array}{c}0.221 \\
(0.000)\end{array}$ & $\begin{array}{c}0.203 \\
(0.000)\end{array}$ & \\
\hline 5. & $\begin{array}{l}\text { Distance covered as a food } \\
\text { attribute }\end{array}$ & $\begin{array}{l}-0.124 \\
(0.005)\end{array}$ & $\begin{array}{c}0.165 \\
(0.000)\end{array}$ & $\begin{array}{c}0.111 \\
(0.012)\end{array}$ & $\begin{array}{c}0.386 \\
(0.000)\end{array}$ \\
\hline
\end{tabular}

Note: The Table contains Pearson correlation coefficients and $p$-values in parentheses.

\section{Discussion}

The CETSCALE was used to study consumer ethnocentric behavior, as it had received preferential application in the literature, with numerous replications. It was also proved that it measures a unidimensional construct and that the measurement error is acceptable [46]. However, alternative scales, including CEESCALE and CES, are recommended by some authors $[47,48]$. The "classical" type of consumer ethnocentrism, at the national level, was examined. It is also possible to study this phenomenon at the subnational level $[28,49]$. Similar to previous research in Poland [50], the CETSCALE item that buying foreign-made food was not patriotic received the lowest support in the sample.

According to this study's results, certain Schwartz values were relevant in predicting consumer ethnocentrism in the food market. This finding is consistent with previous research demonstrating that cultural similarity matters for ethnocentric consumers in the evaluation of imported products [51]. The tradition value was found to be the strongest predictor of consumer ethnocentrism in the model, which confirms its increasing role in food marketing and consumption (see e.g., [52]). The tradition Schwartz value was also a determinant of the willingness to pay (WTP) a price premium for domestic food products [34]. This finding is consistent with the study of Balabanis et al. [53], who found that conservation types of values are positively related to consumer ethnocentrism. Universalism (defined as the importance of looking after the environment and caring for nature) was positively related to the WTP [34], but it was negatively associated with consumer ethnocentrism measured with the CETSCALE index, as demonstrated in the current study. The reasons behind this finding require further investigation. Perhaps, its predictive power was reduced with the addition of the natural content food choice motive in the regression.

Being a student turned out to be a more powerful (negative) predictor of consumer ethnocentrism than belonging to the youngest age segment. Awdziej et al. [35] found that the level of consumer ethnocentrism grows with consumer age. The current findings suggest a nonlinear relationship between age and ethnocentrism. In a study concerning consumer ethnocentrism in the organic food market, age was a significant predictor [54]. Nestorowicz and Kaniewska-Sęba [37] indicated the impact of both age and education on the CETSCALE level.

It is worth noting not only the differences in predictors between men and women (as in some other consumer attitude and behavior studies, e.g., [55,56]), but also it should be underlined that some variables which were significant predictors in the whole sample lost their significance in separate regressions for either gender. These were universalism 
and conformity values, attaching importance to the natural content of food, and being a student. This confirms the theoretical and methodological justification of analyzing consumer ethnocentrism not only in the total sample, but also separately among men and women.

\section{Conclusions}

In order to study the phenomenon of consumer ethnocentrism in the food market, a large-scale survey was conducted in a representative nationwide sample of Polish consumers (1000 participants). Measurement scales of key constructs, which were validated in the literature of the subject, were used. Following previous recommendations that consumer ethnocentrism should be examined separately for various product categories, the study focused on food consumption only. A series of bivariate analyses were applied to identify potential predictors of the CETSCALE level in the food market. The statistically significant variables were included in a multiple regression model to check their simultaneous impact. As the model was rather complex (having 38 independent variables), a smaller set of predictors was needed. Referring to research question RQ1, a satisfactory model with just eight predictors was arrived at with the use of the stepwise regression. They were largely psychographic, with the notable exception of the negative influence of being a student. They included three Schwartz values, two of which had a positive impact on consumer ethnocentrism (tradition and conformity), the pride of being Polish, and three variables, which were characteristic of the food market, the importance attached to the country of origin of the food product, the distance it covers from the producer to the consumer, and natural content as a food choice motive. Therefore, research hypotheses H1-H5 were accepted.

The current findings contribute to the development of the theory of consumer ethnocentrism by improving our understanding of its predictors in the food market. Referring to the research questions RQ2 and RQ3, three predictors affected positively and significantly consumer ethnocentrism in the food market both among men and among women, namely the tradition Schwartz value, pride of being Polish, and importance attached to distance covered by the food product from the producer to the shop, which is related to the preference for local food. Moreover, consumer ethnocentrism among men was dependent on their food choice motive, environmental friendliness, whereas consumer ethnocentrism among women was affected by the importance attached to the product's country of origin, and it was negatively related to women's younger age. Running separate regressions for men and women led to the finding that age was more relevant in predicting consumer ethnocentrism among women than among men, with the youngest age cohort of women (aged 15-24) showing a negative impact on the level of consumer ethnocentrism in the food market. Therefore, research Hypothesis H6 was accepted.

This study has important managerial implications. As the CETSCALE levels were examined in various consumer segments, it is possible to target more precisely one's marketing communications to those consumers who have the highest (or the lowest) level of ethnocentrism. Based on the current findings, it is justified to recommend the use of certain appeals in marketing communications addressed to ethnocentric consumers. Namely, such messages should emphasize the values of tradition and conformity and avoid references to universalism. The pride of being Polish may also be used in such advertising. The following food product characteristics should be underlined as well in order to obtain the preference of ethnocentric consumers: country of origin, low distance from the producer to the shop, and natural content. Finally, as considerable differences in predictors of consumer ethnocentrism were found between men and women, it is recommended to tailor marketing communications to each gender, if possible. In messages addressed to men, environmental friendliness appeals should be used more frequently, whereas in communications targeted at women, country of origin should be emphasized more strongly. 
This study is not devoid of limitations. First, it is based on self-reported rather than observed variables. The survey method enabled investigation of the simultaneous impact of a wide range of variables, and previously validated measurement scales were applied, but the usual bias connected with self-reporting cannot be ruled out completely. Second, this is a single-country study, which means that the composition of consumer Schwartz values in Polish society could affect the statistical significance of some findings. Therefore, it is recommended to replicate this study in other cultural contexts. Third, the sample representativeness criteria were limited to sex, age, education, rural-urban divide, and region. Using additional representativeness criteria could improve the quality of the results, but the selection of criteria was considered as sufficient due to the cost-benefit considerations. Fourth, as the survey was conducted in early 2020, just before the outbreak of the coronavirus pandemic, it does not capture the changes in consumer attitudes and behavior, which occurred during the pandemic (see e.g., [57]).

Funding: This research was funded by the National Science Centre, Opus grant number 2017/25/B/ HS4/00031. The APC was funded by the National Science Centre, Opus grant number 2017/25/B/ HS4/00031.

Institutional Review Board Statement: Ethical review and approval were waived for this study, because according to the Work regulations of the Committee for Research Bioethics of the University of Lodz (attachment to Ordinance No. 149 of the Rector of the University of Lodz of 15.07.2013), the consent of this committee was not required for the kind of studies conducted in this research project. The consent is necessary for biological, medical, chemical, and physical research projects using biological material collected from humans, as well as research interfering with the human psyche. My survey did not fall into these categories.

Informed Consent Statement: Informed consent was obtained from all subjects involved in the study.

Data Availability Statement: The data presented in this study are available on request from the author.

Conflicts of Interest: The author declares no conflict of interest. The funder had no role in the design of the study; in the collection, analyses, or interpretation of data; in the writing of the manuscript, or in the decision to publish the results.

\section{Appendix A}

Table A1. Operationalization of variables used in the regression models.

\begin{tabular}{|c|c|c|c|}
\hline Variable & Items & Scales & References \\
\hline Consumer ethnocentrism & $\begin{array}{l}\text { 10-item CETSCALE adapted } \\
\text { to the food market (items } \\
\text { shown in Table 2) was used to } \\
\text { calculate the CETSCALE } \\
\text { index }\end{array}$ & $\begin{array}{l}\text { 7-1, where } 7 \text { means Definitely } \\
\text { Yes and } 1 \text { Definitely Not }\end{array}$ & [35-37] \\
\hline Age (15-24) & Year of birth & numerical & \\
\hline Household size & $\begin{array}{l}\text { The size of your } \\
\text { household-number of persons }\end{array}$ & numerical & \\
\hline Number of children & $\begin{array}{c}\text { Number of children living } \\
\text { with you }\end{array}$ & numerical & \\
\hline Student & $\begin{array}{c}\text { What is your professional } \\
\text { activity? Student }\end{array}$ & single-choice & \\
\hline $\begin{array}{l}\text { Satisfaction with financial } \\
\text { situation }\end{array}$ & $\begin{array}{l}\text { To what an extent are you } \\
\text { satisfied with the financial } \\
\text { situation of your family } \\
\text { (household)? }\end{array}$ & $\begin{array}{l}\text { 1-10, where } 1 \text { means } \\
\text { Completely Dissatisfied, and } \\
10 \text { Completely Satisfied }\end{array}$ & [39] (question 15) \\
\hline Diet health & $\begin{array}{c}\text { How do you evaluate your } \\
\text { diet? }\end{array}$ & $\begin{array}{l}\text { Very Healthy, Somewhat } \\
\text { Healthy, Average, Somewhat } \\
\text { Unhealthy, Very Unhealthy, } \\
\text { coded 5-1 }\end{array}$ & \\
\hline
\end{tabular}


Table A1. Cont.

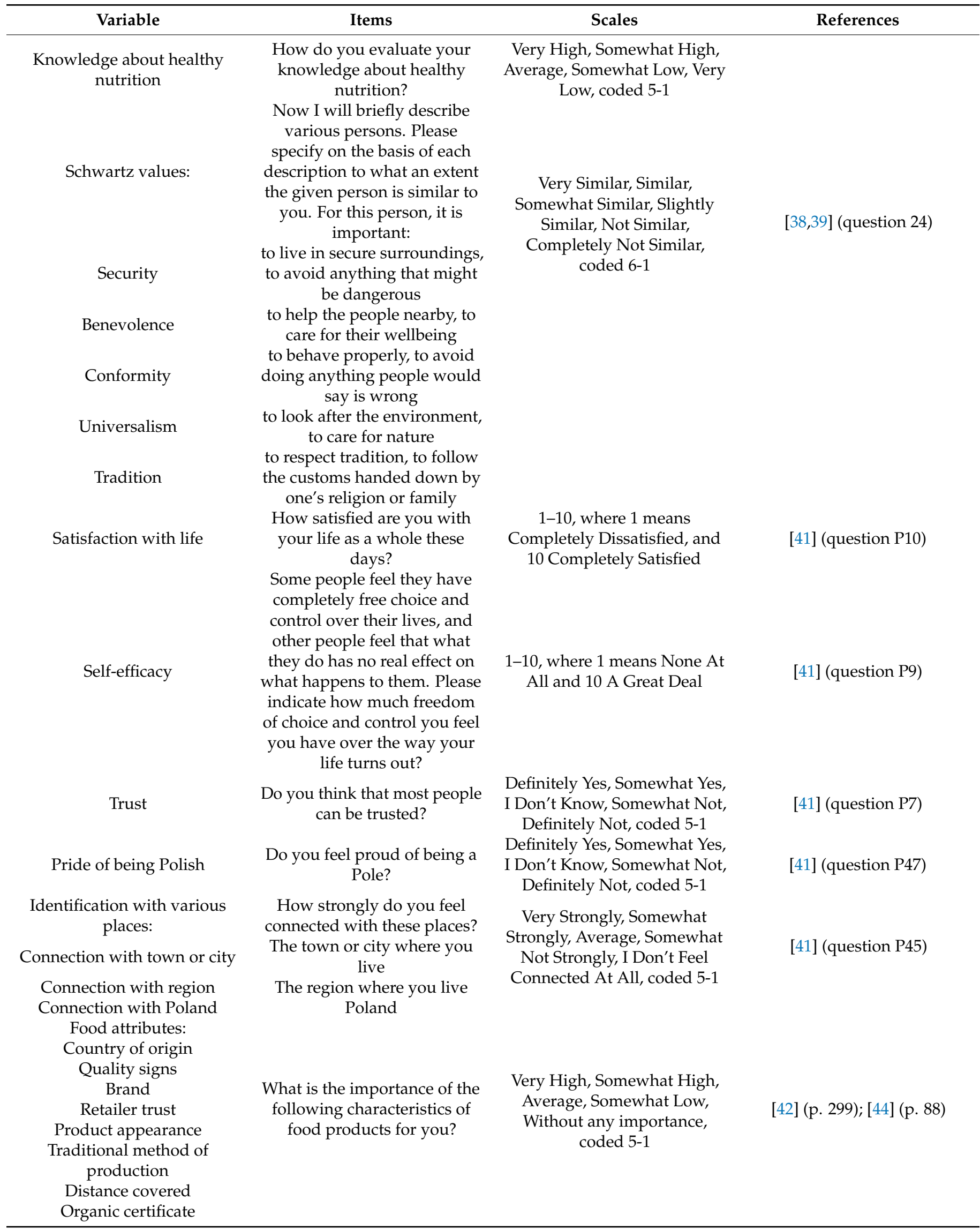


Table A1. Cont.

\begin{tabular}{|c|c|c|c|}
\hline Variable & Items & Scales & References \\
\hline Food choice motives: & $\begin{array}{l}\text { It is important to me that the } \\
\text { food I eat on a typical day: }\end{array}$ & & \\
\hline Health & Is healthy & & \\
\hline Mood & $\begin{array}{l}\text { Is a way of improving my } \\
\text { mood (e.g., a good feeling or } \\
\text { coping with stress) }\end{array}$ & 7-1 scales with 2 anchors: Very & \\
\hline Convenience & $\begin{array}{l}\text { Is convenient (in buying and } \\
\text { preparing) }\end{array}$ & $\begin{array}{c}\text { Important, Not at All } \\
\text { Important }\end{array}$ & {$[29,58]$} \\
\hline Sensory appeal & $\begin{array}{c}\text { Provides me with pleasurable } \\
\text { sensations (e.g., appearance, } \\
\text { smell, taste) }\end{array}$ & & \\
\hline Natural content & Is natural & & \\
\hline Price & Is affordable & & \\
\hline Weight control & Helps me control my weight & & \\
\hline Familiarity & Is familiar & & \\
\hline Environmental friendliness & Is environmentally friendly & & \\
\hline Animal friendliness & $\begin{array}{l}\text { Has been produced in an } \\
\text { animal-friendly way }\end{array}$ & & \\
\hline Fair trade & Is fairly traded & & \\
\hline
\end{tabular}

\section{References}

1. Prince, M. Domestic product involvement and consumer willingness to buy domestic products: Empirical testing of a cognitive consistency theory framework. J. Int. Consum. Mark. 2020, 32, 453-461. [CrossRef]

2. Bernard, Y.; Collange, V.; Ingarao, A.; Zarrouk-Karoui, S. Products labelled as "made in domestic country": The brand matters. Eur. J. Mark. 2020, 54, 2965-2987. [CrossRef]

3. Sun, Y.; Gonzalez-Jimenez, H.; Wang, S. Examining the relationships between e-WOM, consumer ethnocentrism and brand equity. J. Bus. Res. 2021, 130, 564-573. [CrossRef]

4. Blazquez-Resino, J.J.; Gutierrez-Broncano, S.; Jimenez-Estevez, P.; Perez-Jimenez, I.R. The Effect of Ethnocentrism on Product Evaluation and Purchase Intention: The Case of Extra Virgin Olive Oil (EVOO). Sustainability 2021, 13, 4744. [CrossRef]

5. Shahabi Ahangarkolaee, S.; Gorton, M. The effects of perceived regulatory efficacy, ethnocentrism and food safety concern on the demand for organic food. Int. J. Consum. Stud. 2021, 45, 273-286. [CrossRef]

6. Ortega-Egea, J.; García-de-Frutos, N. Mapping the influence of country-of-origin knowledge, consumer ethnocentrism, and perceived risk on consumer action against foreign products. J. Consum. Behav. 2021, 20, 1164-1178. [CrossRef]

7. Balabanis, G.; Diamantopoulos, A. Brand Origin Identification by Consumers: A Classification Perspective. J. Int. Mark. 2008, 16, 39-71. [CrossRef]

8. Seitz, C.C.; Roosen, J. Does consumer ethnocentrism influence product knowledge? Food Qual. Prefer. 2015, 43, 113-121. [CrossRef]

9. Balabanis, G.; Diamantopoulos, A. Domestic country bias, country-of-origin effects, and consumer ethnocentrism: A multidimensional unfolding approach. J. Acad. Mark. Sci. 2004, 32, 80-95. [CrossRef]

10. Fernandez-Ferrin, P.; Calvo-Turrientes, A.; Bande, B.; Artaraz-Minon, M.; Galan-Ladero, M. The valuation and purchase of food products that combine local, regional and traditional features: The influence of consumer ethnocentrism. Food Qual. Prefer. 2018, 64, 138-147. [CrossRef]

11. Lesáková, D. Ethnocentric behaviour in the Slovak population: Do Slovaks purchase Slovak dairy products? Ekon. Cas. 2016, 64, 795-807.

12. Prince, M.; Yaprak, A.N.; Palihawadana, D. The moral bases of consumer ethnocentrism and consumer cosmopolitanism as purchase dispositions. J. Consum. Mark. 2019, 36, 429-438. [CrossRef]

13. Bryła, P. The Importance of Country-of-Origin Information on Food Product Packaging. Nutrients 2021, 13, 3251. [CrossRef] [PubMed]

14. Li, D.; Xie, L. Country-of-origin cues: Effects of country-related affect and product association on consumer responses to hospitality firms. Int. J. Contemp. Hosp. Manag. 2021, 33, 1789-1809. [CrossRef]

15. Shankarmahesh, M. Consumer ethnocentrism: An integrative review of its antecedents and consequences. Int. Mark. Rev. 2006, 23, 145-172. [CrossRef]

16. De Ruyter, K.; Van Birgelen, M.; Wetzels, M. Consumer ethnocentrism in international services marketing. Int. Bus. Rev. 1998, 7, 185-202. [CrossRef]

17. Josiassen, A.; Assaf, A.; Karpen, I. Consumer ethnocentrism and willingness to buy: Analyzing the role of three demographic consumer characteristics. Int. Mark. Rev. 2011, 28, 627-646. [CrossRef] 
18. Akbarov, S. Consumer ethnocentrism and purchasing behaviour: Moderating effect of demographics. J. Islamic Mark. 2021, in press. [CrossRef]

19. Čvirik, M. Consumer ethnocentrism: Comparison of Slovakia and the Czech Republic. Acta Univ. Agric. Silvic. Mendel. Brun. 2021, 69, 259-266. [CrossRef]

20. Matić, M. The Impact of Demographic and Socio-Psychological Factors on Consumers Ethnocentric Tendencies in Croatia. Econ. Res. Ekon. Istraživanja 2013, 26, 1-14. [CrossRef]

21. Correa, S.; Parente-Laverde, A.-M. Consumer Ethnocentrism, Country Image and Local Brand Preference: The Case of the Colombian Textile, Apparel and Leather Industry. Glob. Bus. Rev. 2017, 18, 1111-1123. [CrossRef]

22. Spillan, J.E.; Kang, Z.; Barat, S. A Multi-Country Study Exploring Relationships of Lifestyles to Ethnocentrism. J. Transnatl. Manag. 2011, 16, 62-83. [CrossRef]

23. Siamagka, N.; Balabanis, G. Revisiting consumer ethnocentrism: Review, reconceptualization and empirical testing. J. Int. Mark. 2015, 23, 66-86. [CrossRef]

24. Prince, M.; Yaprak, A.; Cleveland, M.; Davies, M.A.; Josiassen, A.; Nechtelberger, A.; Nechtelberger, M.; Palihawadana, D.; Renner W.; Supekova, S.C.; et al. The psychology of consumer ethnocentrism and cosmopolitanism: A five-country study of values, moral foundations, gender identities and consumer orientations. Int. Mark. Rev. 2020, 37, 1013-1049. [CrossRef]

25. Oleniuch, I.; Cichocka, I. Food conservatism and consumer ethnocentrism of young adults: Relations and references. Intercathedra 2019, 39, 185-193.

26. Fernández-Ferrín, P.; Bande, B.; Galán-Ladero, M.; Martín-Consuegra, D.; Díaz, E.; Castro-González, S. Geographical indication food products and ethnocentric tendencies: The importance of proximity, tradition, and ethnicity. J. Clean. Prod. 2019, 241, 118210. [CrossRef]

27. Han, C.M.; Won, S.B. Cross-country differences in consumer cosmopolitanism and ethnocentrism: A multilevel analysis with 21 countries. J. Consum. Behav. 2018, 17, 52-66. [CrossRef]

28. Bryła, P. Regional Ethnocentrism on the Food Market as a Pattern of Sustainable Consumption. Sustainability 2019, 11, 6408. [CrossRef]

29. Onwezen, M.; Reinders, M.; Verain, M.; Snoek, H. The development of a single-item Food Choice Questionnaire. Food Qual. Prefer. 2019, 71, 34-45. [CrossRef]

30. Van Trijp, H.C.M.; Fischer, A.R.H. Mobilizing consumer demand for sustainable development. In The TransForum Model: Transforming Agro Innovation toward Sustainable Development; van Latesteijn, H., Andeweg, K., Eds.; Springer: Dordrecht, The Netherlands, 2010; pp. 73-96. [CrossRef]

31. Vabø, M.; Hansen, H.; Hansen, K.V.; Kraggerud, H. Ethnocentrism and Domestic Food Choice: Insights from an Affluent Protectionist Market. J. Food Prod. Mark. 2017, 23, 570-590. [CrossRef]

32. Štefko, R.; Bačík, R.; Fedorko, R.; Oleárová, M.; Rigelský, M. Analysis of consumer preferences related to the use of digital devices in the e-commerce dimension. Entrep. Sustain. 2019, 7, 25-33. [CrossRef]

33. Kemmelmeier, M. Gender moderates the impact of need for structure on social beliefs: Implications for ethnocentrism and authoritarianism. Int. J. Psychol. 2010, 45, 202-211. [CrossRef] [PubMed]

34. Bryła, P. The Impact of Consumer Schwartz Values and Regulatory Focus on the Willingness to Pay a Price Premium for Domestic Food Products: Gender Differences. Energies 2021, 14, 6198. [CrossRef]

35. Awdziej, M.; Tkaczyk, J.; Włodarek, D. Are elderly consumer more ethnocentric? Attitudes towards Polish and 'foreign' food products. J. Econ. Manag. 2016, 23, 91-107.

36. Shimp, T.A.; Sharma, S. Consumer ethnocentrism: Construction and validation of the CETSCALE. J. Mark. Res. 1987, XXIV, 280-289. [CrossRef]

37. Nestorowicz, R.; Kaniewska-Sęba, A. Zastosowanie CETSCALE do pomiaru etnocentryzmu konsumenckiego na rynku produktów żywnościowych w Polsce. Mark. I Rynek 2014, 6, 501-517. (In Polish)

38. Schwartz, S.H. A Proposal for Measuring Value Orientations across Nations. 2001. Available online: https://www. europeansocialsurvey.org/methodology/ess_methodology/source_questionnaire/source_questionnaire_development.html (accessed on 7 April 2021).

39. CBOS. Wartości Cenione w Życiu. Research Survey 2012/04. 2012. Available online: https://www.worldvaluessurvey.org/ WVSDocumentationWV6.jsp (accessed on 7 April 2021).

40. Schwartz, S.H. A Repository of Schwartz Value Scales with Instructions and an Introduction. Online Read. Psychol. Cult. 2021, 2. [CrossRef]

41. European Values Study. 2017 Questionnaire Poland. 2017. Available online: https:// europeanvaluesstudy.eu/methodology-datadocumentation/survey-2017/full-release-evs2017/participating-countries-and-country-information-survey-2017/ (accessed on 7 April 2021).

42. Bryła, P. Marketing Regionalnych i Ekologicznych Produktów Żywnościowych. Perspektywa Sprzedawcy i Konsumenta; Wydawnictwo Uniwersytetu Łódzkiego: Łódź, Poland, 2015; (In Polish). [CrossRef]

43. Bryła, P. Organic food online shopping in Poland. Br. Food J. 2018, 120, 1015-1027. [CrossRef] 
44. Nestorowicz, R.; Pilarczyk, B.; Jerzyk, E.; Rogala, A.; Disterheft, A. Raport z Badań Przeprowadzonych w Ramach Projektu "Postawy Etnocentryczne Konsumentów (w Ujęciu Lokalnym) a Szanse i Bariery Rozwoju Rynku Żywności Ekologicznej". 2016. Available online: https://ue.poznan.pl/data/upload/articles/20161117/e3ce22140925691154/postay-etnocentrycznekonsumentow-a-szanse-i-bariery-rozwoju-rynku-zywnosci-ekologicznej.pdf (accessed on 9 April 2021). (In Polish).

45. Central Statistical Office. Statistical Yearbook of the Republic of Poland; Central Statistical Office: Warsaw, Poland, 2020.

46. Luque-Martínez, T.; Ibáñez-Zapata, J.; Barrio-García, S. Consumer ethnocentrism measurement-An assessment of the reliability and validity of the CETSCALE in Spain. Eur. J. Mark. 2000, 34, 1353-1374. [CrossRef]

47. Jiménez-Guerrero, J.F.; Pérez-Mesa, J.C.; Galdeano-Gómez, E. Alternative Proposals to Measure Consumer Ethnocentric Behavior: A Narrative Literature Review. Sustainability 2020, 12, 2216. [CrossRef]

48. Sharma, P. Consumer ethnocentrism: Reconceptualization and cross-cultural validation. J. Int. Bus. Stud. 2015, 46, 381-389. [CrossRef]

49. Fernández-Ferrín, P.; Bande, B.; Martín-Consuegra, D.; Díaz, E.; Kastenholz, E. Sub-national consumer ethnocentrism and the importance of the origin of food products: An exploratory analysis. Br. Food J. 2020, 122, 995-1010. [CrossRef]

50. Sajdakowska, M. Etnocentryzm konsumencki-Czynnik wpływający na decyzje nabywcze konsumentów na rynku żywności. Acta Sci. Polonorum. Technol. Aliment. 2003, 2, 177-184. (In Polish)

51. Watson, J.; Wright, K. Consumer ethnocentrism and attitudes toward domestic and foreign products. Eur. J. Mark. 2000, 34, 1149-1166. [CrossRef]

52. Bryła, P. The role of appeals to tradition in origin food marketing. A survey among Polish consumers. Appetite 2015, 91, 302-310. [CrossRef]

53. Balabanis, G.; Mueller, R.; Melewar, T.C. The Relationship between Consumer Ethnocentrism and Human Values. J. Glob. Mark. 2002, 15, 7-37. [CrossRef]

54. Bryła, P. Consumer ethnocentrism on the organic food market in Poland. Mark. I Zarzadzanie 2017, 2, 11-20. [CrossRef]

55. Nagoya, R.; Surya Wanasida, A.; Purwanto, A.; Rafdinal, W. Why do people buy Chinese smart phones: The role of ethnocentrism, value and gender. Ann. Rom. Soc. Cell Biol. 2021, 25, 16267-16290.

56. Tirelli, C.; Martínez-Ruiz, M.P.; Gómez-Ladrón-De-Guevara, R. Assessing the impact of ethnocentrism in the food buying decisions of international university students. J. Food Prod. Mark. 2016, 22, 279-303. [CrossRef]

57. Valaskova, K.; Durana, P.; Adamko, P. Changes in Consumers' Purchase Patterns as a Consequence of the COVID-19 Pandemic. Mathematics 2021, 9, 1788. [CrossRef]

58. Steptoe, A.; Pollard, T.; Wardle, J. Development of a measure of the motives underlying the selection of food: The Food Choice Questionnaire. Appetite 1995, 25, 267-284. [CrossRef] [PubMed] 